\title{
ANALISIS PENYEBAB KESULITAN BELAJAR MAHASISWA DALAM PEMBELAJARAN KONSTRUKTIVISTIK MATA KULIAH ALJABAR LINIER
}

\author{
Nur Wasito ${ }^{1)}$ Fandi Ahmad Kurniawan') \\ 1) AMIK PGRI Kebumen, Kebumen, Indonesia \\ Email: scientistmuda86@gmail.com \\ 2) AMIK PGRI Kebumen, Kebumen, Indonesia
}

\begin{abstract}
Abstrak. Penelitian ini dilatarbelakangi oleh adanya kesulitan-kesulitan belajar yang dialami mahasiswa dalam pembelajaran konstruktivistik mata kuliah Aljabar Linier yang menyebabkan prestasi belajar mereka relatif rendah, padahal penelitian-penelitian sebelumnya mengatakan bahwa kelas yang diajar menggunakan pembelajaran konstruktivistik cenderung mempunyai prestasi belajar yang tinggi. Tujuan penelitian ini adalah untuk mendeskripsikan faktor-faktor penyebab terjadinya kesulitan-kesulitan belajar yang dialami mahasiwa dalam pembelajaran konstruktivistik mata kuliah Aljabar Linier. Penelitian ini menggunakan pendekatan deskriptif kualitatif. Metode pengumpulan data yang digunakan yaitu observasi, angket dan wawancara. Analisis data yang digunakan menggunakan model Miles dan Huberman yang meliputi: mereduksi data, menyajikan data dan menarik kesimpulan. Triangulasi metode digunakan dalam penelitian ini untuk menambah derajat keabsahan data. Hasil penelitian ini adalah deskripsi faktor-faktor penyebab kesulitankesulitan belajar yang dialami mahasiswa dalam pembelajaran konstruktivistik mata kuliah Aljabar Linier diantaranya yaitu faktor mahasiswa yang tidak percaya diri untuk mengkomunikasikan ide/pendapatnya, faktor modul Aljabar Linier yang belum mengarahkan kepada penemuan konsep, faktor kurang bisanya mahasiswa untuk menganalisis masalah yang baru pertama ditemui, serta faktor yang paling utama adalah belum terbiasanya mahasiswa dengan pembelajaran yang menekankan untuk mengkonstruksi sendiri pengetahuannya.
\end{abstract}

Kata kunci: penyebab kesulitan belajar, konstruktivistik, aljabar linier.

\section{PENDAHULUAN}

Mata kuliah Aljabar Linier merupakan mata kuliah wajib bagi mahasiswa program studi manajemen informatika AMIK PGRI Kebumen. Pemberian mata kuliah ini pada mahasiswa program studi Manajemen Informatika, dimaksudkan agar mahasiswa mampu menguasai teknik-teknik dasar Aljabar Linier dan mampu mengaplikasikannya dalam menyelesaikan masalah. Agar mahasiswa mampu menguasai teknik-teknik dasar Aljabar Linier dan mampu mengaplikasikannya untuk menyelesaikan masalah, mahasiswa dituntut tidak hanya mengahafal rumus saja tetapi lebih dari itu adalah memahami konsep dengan benar agar mampu mengaplikasikannya untuk menyelesaikan masalah.

Sejalan dengan hal tersebut, pembelajaran pada mata kuliah Aljabar Linier membutuhkan sebuah pendekatan pembelajaran yang menekankan pada pemahaman konsep yang baik oleh peserta didik. Nizarwati dkk (2009) menyatakan bahwa kemampuan pemahaman konsep peserta didik akan menjadi sangat baik apabila menggunakan pendekatan pembelajaran yang berorientasi konstruktivis.

Menurut Nickson (Hudoyo, 2005) pembelajaran yang sesuai dengan pandangan konstruktivis adalah pembelajaran yang membantu peserta didik membangun konsep-konsep dengan kemampuanya sendiri melalui proses internalisasi sehingga konsep-konsep tersebut terbangun kembali menjadi konsep baru.

Rahman dan scaife (2012) mengatakan bahwa lingkungan belajar yang konstruktivis berasumsi dapat membuat peserta didik aktif membangun pemahaman mereka sendiri, sehingga pengetahuan-pengetahuan tidak hanya merupakan salinan dari pihak luar, tidak pula pengetahuan dari penyerapan pasif ataupun sebatas transfer pengetahuan yang sederhana dari pendidik kepada peserta didik. Mucholid (2015) juga mengatakan bahwa penggunaan pendekatan konstruktivistik pada pembelajaran menunjukkan peningkatan aktivitas dan 


\section{- - - Jurnal Pendidikan Matematika Indonesia \\ Volum 3 Nomor 2 Bulan September 2018 Page 47 - 51 \\ p-ISSN: 2477-5967 e-ISSN: 2477-8443}

prestasi belajar peserta didik. Hal senada juga diungkapkan Abdurrahman (2002) yang menyatakan bahwa pada pembelajaran konstruktivis terjadi peningkatan perolehan hasil belajar yang cukup signifikan.

Yager (Rosalin, 2008) menerangkan bahwa tahap-tahap pembelajaran konstruktivistik meliputi 4 tahap yaitu: tahap Invitasi, tahap eksplorasi, tahap pengajuan eksplanasi dan solusi, serta tahap taking action. Tahap invitasi yaitu mengidentifikasi konsepsi awal peserta didik, misalnya: mengamati keingintahuan peserta didik, memahami situasi yang diharapkan peserta didik ataupun menanyakan pertanyaan kepada peserta didik dan memintanya mempertimbangkan kemungkinan jawabannya. Tahap eksplorasi yaitu peserta didik secara aktif menggali informasi-informasi baru, misalnya: melakukan percobaan dan penyelidikan, mengumpulkan dan mengolah data ataupun mencoba strategi-strategi untuk menyelesaikan masalah. Tahap pengajuan eksplanasi dan solusi yaitu proses diskusi peserta didik baik secara kelompok maupun individu untuk memperoleh penjelasan dan solusi, misalnya: mengkomunikasikan informasi atau ide-ide, membangun suatu penjelasan baru, ataupun mereview dan mengupas solusi suatu permasalahan. Tahap taking action yaitu merumuskan hasil eksplorasi serta pemberian evaluasi, misalnya: membuat keputusan, menggunakan pengetahuan dan keterampilan yang sudah diperolehnya ataupun mengembangkan ide dan hasil.

Peneliti sekaligus dosen pengampu mata kuliah Aljabar Linier pada program studi Manajemen Informatika AMIK PGRI Kebumen telah menerapkan pendekatan pembelajaran konstruktivistik dalam perkuliahan Aljabar Linier pada dua tahun akademik yaitu 2015/2016 dan 2016/2017. Akan tetapi prestasi belajar mata kuliah Aljabar Linier yang diperoleh mahasiswa pada dua tahun akdemik tersebut relatif rendah. Padahal penelitian-penelitian sebelumnya menyatakan bahwa kelas yang diajar menggunakan pendekatan pembelajaran konstruktivistik cenderung mempunyai prestasi belajar yang lebih baik.

Penelitian awal yang dilakukan peneliti mengindikasikan adanya fenomena-fenomena kesulitan belajar yang dialami mahasiswa dalam penerapan pembelajaran konstruktivistik mata kuliah Aljabar Linier yaitu:

1. Kesulitan menggali pengetahuan awal yang dimilikinya.

2. Kesulitan mengkomunikasikan pengetahuan awal yang dimilikinya.

3. Kesulitan melakukan penyelidikan dalam rangka menemukan sendiri konsep.

4. Kesulitan mengkomunikasikan hasil penyelidikan yang telah dilakukan.

5. Kesulitan mengaplikasikan konsep materi untuk menyelesaikan masalah.

Menurut Jamaris, dalam Pramudya (2016) kesulitan belajar adalah kelainan pada individu yang mengalami kesulitan dalam melakukan proses pembelajaran yang efektif. Jamaris juga berpendapat bahwa kesulitan belajar tidak berkaitan dengan intelegensi seseorang, namun berkaitan dengan kesulitan seseorang dalam menguasai keterampilan belajar.

Berdasarkan latar belakang tersebut, peneliti berusaha untuk meneliti tentang faktor-faktor yang menyebabkan terjadinya kesulitan-kesulitan belajar yang dialami mahasiswa dalam pembelajaran konstruktivistik mata kuliah Aljabar Linier program studi Manajemen Informatika AMIK PGRI Kebumen.

Tujuan dari penelitian ini adalah memperoleh deskripsi faktor-faktor yang menyebabkan terjadinya kesulitan-kesulitan belajar yang dialami mahasiswa dalam pembelajaran konstruktivistik mata kuliah Aljabar Linier.

\section{METODE}

Penelitian ini menggunakan pendekatan deskriptif kualitatif yang menekankan pada pengamatan secara mendalam tentang faktor-faktor yang menyebabkan terjadinya kesulitan-kesulitan belajar mahasiswa dalam pembelajaran konstruktivistik mata kuliah Aljabar Linier. Menurut Moleong (2011: 6) penelitian kualitatif adalah penelitian yang berusaha untuk memahami fenomena tentang apa yang dialami oleh objek penelitian misalnya perilaku, persepsi, motivasi, tindakan, dan lain-lain secara holistik dengan cara mendeskripsikannya dalam bentuk kata-kata dan bahasa.

Pendekatan kualitatif dipakai sebagai pendekatan dalam penelitian ini karena berguna untuk memahami kondisi realitas dari objek yang diteliti. Metode observasi, wawancara, dan angket dilakukan untuk menggali informasi mengenai faktorfaktor yang menyebabkan terjadinya kesulitan belajar mahasiswa dalam pembelajaran konstruktivistik mata kuliah Aljabar Linier.

Observasi dilakukan pada saat pembelajaran mata kuliah aljabar linier terhadap seluruh mahasiswa di kelas tersebut. Metode wawancara yang digunakan adalah wawancara tersetruktur terhadap 2 orang mahasiswa yang memiliki prestasi belajar dengan kategori tinggi yang mana 1 orang sudah bekerja dan 1 orang lagi belum bekerja, kemudian 2 orang mahasiswa dengan prestasi belajar kategori sedang yang mana 1 orang sudah bekerja dan satu lagi belum bekerja, serta 2 orang mahasiswa dengan prestasi belajar kategori rendah juga terdiri dari 1 orang yang sudah bekerja dan 1 orang lagi yang belum bekerja. Sedangkan angket diberikan kepada seluruh mahasiswa yang mengambil mata kuliah aljabar linier tersebut.

Masing-masing objek penelitian akan diberikan koding yang berbeda-beda agar data lebih sistematis, hal ini senada dengan Cresswel (2012) koding akan membuat peneliti lebih sistematis dalam proses analisis data tekstual. Data yang diperoleh dari hasil wawancara, angket dan observasi tersebut kemudian dilakukan analisis data.

Aktivitas analisis data pada penelitian ini menggunakan model Miles dan Huberman (Sugiyono, 2009) yaitu meliputi: mereduksi data, menyajikan data dan menarik kesimpulan. Mereduksi data berarti merangkum, memilih hal-hal yang pokok, memfokuskan pada hal-hal yang penting, dicari tema dan polanya. Setelah data direduksi, maka langkah selanjutnya adalah menyajikan data. Dalam penelitian kualitatif, penyajian data dapat dilakukan dalam bentuk uraian singkat, tabel, hubungan antar kategori, flowchart dan sejenisnya. Langkah selanjutnya dalam analisis data kualitatif adalah penarikan kesimpulan atas data dan temuan penelitian.

Adapun pengecekan keabsahan data penelitian ini adalah menggunakan triangulasi metode yaitu dengan mengecek 
temuan-temuan penelitian dari berbagai metode pengumpulan data yang dilakukan yaitu observasi, angket dan wawancara. Hal ini dilakukan untuk menghilangkan perbedaan-perbedaan konstruksi data yang diperoleh dari penelitian.

\section{HASIL DAN PEMBAHASAN}

Hasil penelitian ini berupa deskripsi faktor-faktor yang menyebabkan terjadinya kesulitan-kesulitan belajar yang dialami mahasiswa dalam pembelajaran konstruktivistik mata kuliah Aljabar Linier program studi Manajemen Informatika AMIK PGRI Kebumen tahun akademik 2017/2018.

Tabel I menyajikan deskripsi kategori kondisi dari tiap-tiap persentase yaitu sebagai berikut:

Tabel I

Deskripsi kategori kondisi dari tiap-tiap persentase

\begin{tabular}{ll}
\hline Persentase & Kategori \\
\hline $100 \%$ & Seluruhnya \\
$76 \%-99 \%$ & Hampir Seluruhnya \\
$51 \%-75 \%$ & Sebagian Besar \\
$50 \%$ & Separuhnya \\
$26 \%-49 \%$ & Hampir Separuhnya \\
$1 \%-25 \%$ & Sebagian Kecil \\
$0 \%$ & Tidak Ada \\
\hline
\end{tabular}

Adapun Tabel II menyajikan deskripsi kategori kesesuaian dari tiap-tiap persentase yaitu sebagai berikut:

Tabel II

Deskripsi kategori kesesuaian dari tiap-tiap persentase

\begin{tabular}{ll}
\hline Persentase & Kategori \\
\hline $81 \%-100 \%$ & Sangat Sesuai \\
$61 \%-80 \%$ & Sesuai \\
$41 \%-60 \%$ & Cukup Sesuai \\
$21 \%-40 \%$ & Kurang Sesuai \\
$0 \%-20 \%$ & Tidak Sesuai \\
\hline
\end{tabular}

Berdasarkan temuan-temuan dari penelitian, diperoleh faktor-faktor penyebab kesulitan-kesulitan belajar yang dialami mahasiswa adalah sebagai berikut:

1. Deskripsi faktor-faktor penyebab kesulitan mahasiswa dalam menggali pengetahuan awal yang dimilikinya, dapat dilihat pada Tabel III berikut ini.

Tabel III

Deskripsi faktor-faktor penyebab kesulitan mahasiswa dalam menggali pengetahuan awal yang dimiliki

\begin{tabular}{ll}
\hline Faktor Penyebab & Kategori \\
\hline Kurang bisa memulai pembelajaran dengan & Cukup \\
fokus. & Sesuai \\
Kurang memiliki minat terhadap mata & Cukup \\
kuliah Aljabar Linier. & Sesuai
\end{tabular}

\begin{tabular}{ll}
\hline Faktor Penyebab & Kategori \\
\hline $\begin{array}{l}\text { Rendahnya daya ingat mahasiswa terhadap } \\
\text { materi-materi perkuliahan sebelumnya. }\end{array}$ & Sesuai \\
Kondisi kelas yang kurang kondusif. & $\begin{array}{l}\text { Cukup } \\
\text { Sesuai }\end{array}$ \\
\hline
\end{tabular}

Rendahnya daya ingat mahasiswa terhadap materi-materi perkuliahan sebelumnya merupakan faktor yang termasuk kategori sesuai menjadi penyebab kesulitan mahasiswa menggali pengetahuan awal yang dimilikinya. Faktor ini menjadi penyebab bagi sebagian besar mahasiswa Berdasarkan hasil wawancara dapat diketahui bahwa faktor ini menjadi penyebab bagi mahasiswa yang mempunyai prestasi belajar kategori rendah dan sedang, baik mereka yang kuliah sambil bekerja maupun yang belum bekerja.

Sedangkan faktor kurang bisa memulai pembelajaran dengan fokus, kurang memiliki minat terhadap mata kuliah Aljabar Linier dan kondisi kelas yang kurang kondusif merupakan faktor-faktor yang termasuk kategori cukup sesuai menjadi penyebab kesulitan mahasiswa menggali pengetahuan awal yang dimilikinya. Faktor ini menjadi penyebab bagi hampir separuh mahasiswa. Berdasarkan hasil wawancara dapat diketahui bahwa faktor kurang bisa memulai pembelajaran dengan fokus menjadi faktor penyebab bagi mahasiswa yang mempunyai prestasi belajar kategori rendah khususnya mereka yang kuliah sambil bekerja. Sedangkan faktor kurang memiliki minat terhadap mata kuliah Aljabar Linier dan faktor kondisi kelas yang kurang kondusif menjadi penyebab bagi mahasiswa yang mempunyai prestasi belajar kategori rendah baik mereka yang kuliah sambil bekerja maupun yang belum bekerja.

2. Deskripsi faktor-faktor penyebab kesulitan mahasiswa mengkomunikasikan pengetahuan awal yang dimilikinya, dapat dilihat pada Tabel IV berikut ini.

\section{Tabel IV}

Deskripsi faktor-faktor penyebab kesulitan mahasiswa mengkomunikasikan pengetahuan awal yang dimiliki

\begin{tabular}{ll}
\hline Faktor Penyebab & Kategori \\
\hline $\begin{array}{l}\text { Kurang percaya diri menyampaikan } \\
\text { ide/pendapat. }\end{array}$ & Sesuai \\
$\begin{array}{l}\text { Kurang bisa menghubungkan antar } \\
\text { materi. }\end{array}$ & Sesuai \\
\hline
\end{tabular}

Berdasarkan Tabel IV tersebut, faktor kurang percaya diri menyampaikan ide/pendapatnya dan faktor kurang bisa menghubungkan antar materi menjadi faktor dengan kategori sesuai yang menjadi penyebab kesulitan mahasiswa dalam mengkomunikasikan pengetahuan awalnya. Kedua faktor ini menjadi penyebab bagi sebagian besar mahasiswa. Berdasarkan hasil wawancara dapat diketahui bahwa faktorfaktor menjadi penyebab bagi mahasiswa yang mempunyai prestasi belajar kategori rendah dan sedang, baik mereka yang kuliah sambil bekerja maupun yang belum bekerja. 


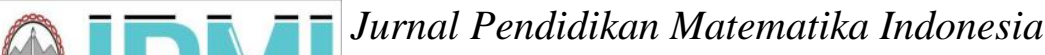 \\ Volum 3 Nomor 2 Bulan September 2018 Page 47 - 51 \\ p-ISSN: 2477-5967 e-ISSN: 2477-8443}

3. Deskripsi faktor-faktor penyebab kesulitan mahasiswa melakukan penyelidikan dalam rangka menemukan sendiri konsep, dapat dilihat pada Tabel V berikut ini.

\section{Tabel V}

Deskripsi faktor-faktor penyebab kesulitan mahasiswa melakukan penyelidikan dalam rangka menemukan sendiri konsep.

\begin{tabular}{ll}
\hline Faktor Penyebab & Kategori \\
\hline $\begin{array}{l}\text { Kurang mampu memahami simbol-simbol } \\
\text { matematika. }\end{array}$ & $\begin{array}{l}\text { Kurang } \\
\text { Sesuai }\end{array}$ \\
$\begin{array}{l}\text { Kurang terbiasa dengan pembelajaran yang } \\
\text { menekankan untuk mengkonstruksi sendiri }\end{array}$ & Sangat \\
pengetahuannya. & Sesuai \\
$\begin{array}{l}\text { Modul Aljabar Linier yang tidak } \\
\text { mengarahkan pada penemuan konsep. }\end{array}$ & Sesuai \\
$\begin{array}{l}\text { Kurang memiliki sumber belajar yang } \\
\text { memadai. }\end{array}$ & Sesuai \\
\hline
\end{tabular}

Berdasarkan Tabel V bisa dilihat bahwa faktor kurang terbiasa dengan pembelajaran yang menekankan untuk mengkonstruksi sendiri pengetahuannya (pembelajaran konstruktivistik) merupakan faktor yang termasuk kategori sangat sesuai menjadi penyebab kesulitan mahasiswa melakukan penyelidikan dalam rangka menemukan sendiri konsep. Faktor ini menjadi penyebab bagi seluruh mahasiswa baik mereka yang mempunyai prestasi belajar kategori rendah, sedang maupun tinggi.

Sedangkan faktor modul Aljabar Linier yang tidak mengarahkan pada penemuan konsep dan faktor kurangnya sumber belajar yang memadai menjadi faktor-faktor yang termasuk kategori sesuai menjadi penyebab kesulitan mahasiswa melakukan penyelidikan untuk menemukan sendiri konsep. Faktor-faktor ini menjadi penyebab bagi sebagian besar mahasiswa. Berdasarkan hasil wawancara dapat diketahui bahwa kedua faktor ini menjadi penyebab bagi mahasiswa yang mempunyai prestasi belajar dengan kategori rendah, sedang maupun tinggi.

Sedangkan faktor mahasiswa kurang mampu memahami simbol-simbol matematika merupakan faktor yang termasuk kategori kurang sesuai menjadi penyebab kesulitan mahasiswa melakukan penyelidikan untuk menemukan sendiri konsep. Hal ini dikarenakan faktor kurang mampu memahami simbolsimbol matematika hanya dirasakan oleh sebagian kecil mahasiswa terutama mereka yang memang dari sejak masa sekolah sudah mempunyai masalah dengan simbol-simbol matematika.

4. Deskripsi faktor-faktor penyebab kesulitan mahasiswa mengkomunikasikan hasil penyelidikan yang telah dilakukannya, dapat dilihat pada Tabel VI berikut ini.
Tabel VI

Deskripsi faktor-faktor penyebab kesulitan mahasiswa mengkomunikasikan hasil penyelidikan yang telah dilakukannya.

\begin{tabular}{ll}
\hline Faktor Penyebab & Kategori \\
\hline $\begin{array}{l}\text { Kurang percaya diri menyampaikan } \\
\text { ide/pendapat. }\end{array}$ & Sesuai \\
$\begin{array}{l}\text { Kurangnya waktu yang diberikan } \\
\text { dosen untuk melakukan penyelidikan } \\
\text { dalam rangka menemukan sendiri }\end{array}$ & Cukup \\
konsep. & \\
\hline
\end{tabular}

Berdasarkan Tabel VI dapat dilihat bahwa faktor kurangnya rasa percaya diri mahasiswa untuk menyampaikan ide/pendapatnya merupakan faktor yang termasuk kategori sesuai menjadi penyabab kesulitan mahasisa mengkomunikasikan hasil penyelidikannya. Faktor ini dirasakan oleh sebagian besar mahasiswa. Berdasarkan hasil wawancara dapat diketahui bahwa faktor ini menjadi penyebab bagi mereka yang mempunyai prestasi belajar dengan kategori rendah dan sedang.

Sedangkan faktor kurangnya waktu yang diberikan dosen untuk mahasiswa melakukan penyelidikan dalam rangka menemukan sendiri konsep merupakan faktor yang termasuk kategori cukup sesuai. Faktor ini menjadi penyebab bagi hampir separuh mahasiswa. Berdasarkan hasil wawancara, justru faktor ini dianggap menjadi penyebab kesulitan mahasiswa mengkomunikasikan hasil penyelidikannya oleh mereka yang mempunyai prestasi belajar dengan kategori tinggi. .

5. Deskripsi faktor-faktor penyebab kesulitan mahasiswa mengaplikasikan konsep materi untuk menyelesaikan masalah, dapat dilihat pada Tabel VII berikut ini.

\section{Tabel VII}

Deskripsi faktor-faktor penyebab kesulitan mahasiswa mengaplikasikan konsep materi untuk menyelesaikan masalah.

\begin{tabular}{ll}
\hline Faktor Penyebab & Kategori \\
\hline $\begin{array}{l}\text { Bingung konsep mana yang harus digunakan } \\
\text { untuk menyelesaikan masalah. }\end{array}$ & Sesuai \\
$\begin{array}{ll}\text { Kurang bisa menganalisis masalah yang } \\
\text { baru ditemui. }\end{array}$ & Sesuai \\
Kurang bisa fokus dalam jangka waktu yang & Cukup \\
lama. & Sesuai \\
Soal-soal yang diberikan dosen kurang & Cukup \\
bervariasi. & Sesuai \\
\hline
\end{tabular}

Berdasarkan Tabel VII tersebut, bisa dilihat bahwa faktor bingung konsep mana yang harus digunakan dan faktor kurang bisa menganalisis masalah yang baru ditemui menjadi faktor yang termasuk kategori sesuai menjadi penyebab kesulitan mahasiswa mengaplikasikan konsep materi untuk menyelesaikan masalah. Kedua faktor ini menjadi penyebab bagi sebagian besar mahasiswa. Berdasarkan hasil wawancara 
dapat diketahui bahwa kedua faktor ini menjadi penyebab bagi mahasiswa yang mempunyai prestasi belajar kategori rendah, sedang maupun tinggi.

Sedangkan faktor kurang bisa fokus dalam jangka waktu yang lama dan faktor dosen dalam memberikan soal-soal yang kurang bervariasi menjadi faktor-faktor yang termasuk kategori cukup sesuai menjadi penyebab kesulitan mahasiswa mengaplikasikan konsep dalam menyelesaikan masalah. Faktor kurang bisa fokus dalam jangka waktu yang lama menjadi menjadi penyebab bagi hampir separuh mahasiswa terutama mereka yang kuliah sambil bekerja baik mereka yang mempunyai prestasi belajar kategori rendah, sedang bahkan tinggi. Adapun faktor dosen dalam memberikan soal-soal yang kurang bervariasi menjadi penyebab bagi hampir separuh mahasiswa terutama mereka yang mempunyai prestasi belajar dengan kategori rendah baik yang kuliah sambil bekerja maupun yang belum bekerja.

\section{KESIMPULAN}

Berdasarkan data dan temuan penelitian tentang faktorfaktor penyebab kesulitan-kesulitan belajar yang dialami mahasiswa dalam pembelajaran konstruktivistik mata kuliah Aljabar Linier program studi Manajemen Informatika AMIK PGRI Kebumen dapat disimpulkan sebagai berikut:

1. Faktor-faktor penyebab kesulitan mahasiswa dalam menggali pengetahuan awal yang dimilikinya yaitu:

a. Kurang bisa memulai pembelajaran dengan fokus.

b. Kurang memiliki minat terhadap mata kuliah Aljabar Linier.

c. Memiliki daya ingat yang rendah terhadap materimateri perkuliahan sebelumnya.

d. Kondisi kelas yang kurang kondusif.

2. Faktor-faktor penyebab kesulitan mahasiswa dalam mengkomunikasikan pengetahuan awal yang dimilikinya yaitu:

a. Kurang percaya diri menyampaikan ide/pendapat.

b. Kurang bisa menghubungkan antar materi.

3. Faktor-faktor penyebab kesulitan mahasiswa dalam melakukan penyelidikan untuk menemukan sendiri konsep yaitu:

a. Kurang terbiasa dengan pembelajaran yang menekankan untuk mengkonstruksi sendiri pengetahuaanya.

b. Modul Aljabar Linier yang tidak mengarahkan pada penemuan konsep.

c. Kurang memiliki sumber-sumber belajar yang memadai.

4. Faktor-faktor penyebab kesulitan mahasiswa dalam mengkomunikasikan hasil penyelidikannya yaitu:

a. Kurang percaya diri menyampaikan ide/pendapat.

b. Kurangnya waktu yang diberikan dosen untuk melakukan penyelidikan dalam rangka menemukan sendiri konsep.

5. Faktor-faktor penyebab kesulitan mahasiswa dalam mengaplikasikan konsep untuk menyelesaikan masalah yaitu:

a. Bingung konsep mana yang harus digunakan untuk menyelesaikan masalah. b. Kurang bisa menganalisis masalah yang baru dijumpai.

c. Kurang bisa fokus dalam jangka waktu yang lama.

d. Soal-soal yang diberikan dosen kurang bervariasi.

\section{UCAPAN TERIMA KASIH}

Ucapan terima kasih penulis sampaikan kepada Direktorat Riset dan Pengabdian Masyarakat (DRPM) Kementrian Riset Teknologi dan Pendidikan Tinggi yang telah membiayayai penelitian ini dalam skema Penelitian Dosen Pemula (PDP), serta semua pihak yang telah membantu dalam penelitian ini.

\section{DAFTAR PUSTAKA}

Abdurrahman. 2002. Efektivitas Model Konstruktivisme dalam Pembelajaran Matematika pada Siswa SMU. Tesis. Tidak Diterbitkan. Bandung: Universitas Pendidikan Indonesia

Creswell, J.W. 2012. Research Design Pendekatan Kualitatif, Kuantitatas dan Mixed. Pustaka Siswa: Yogyakarta

Hudoyo, H. 2005. Kapita Selekta Pembelajaran Matematika. Malang: UM PRESS.

Moleong, L.J. 2011. Metodologi Penelitian Kualitatif Edisi Revisi. Bandung: Rosdakarya.

Mucholid. 2015. Penerapan Pendekatan Konstruktivisme dalam Pembelajaran Matematika untuk Meningkatkan Prestasi Belajar Materi Persamaan Linier Dua Variabel Siswa Kelas VIII-D SMP Negeri 1 Pogalan Kabupaten Trenggalek Semestrer I Tahun 2013/2014. JUPEDASMEN 1(3): 75-80.

Nizarwati, dkk. 2009. Pengembangan Perangkat Pembelajaran Berorientasi Konstruktivisme untuk Mengajarkan Konsep Perbandingan Trigonometri Siswa Kelas X SMA . Jurnal pendidikan Matematika 3(2): 57-72.

Pramudya, Nickholas Damar. 2016. Analisis Kesulitan Belajar Siswa Kelas VIII dalam Pembelajaran Matematika Menggunakan Pendekatan Saintifik Di SMPN 15 Yogyakarta. Skripsi. Tidak Diterbitkan. Fakultas Keguruan dan Ilmu Pendidikan. Yogyakarta: Universitas Sanata Dharma

Rahman dan Scaife. 2012. Sustaining Constructive Learning Environment: The Role of Multi sources Regulation. Procedia-Social and Behavioral Sciences 35: 180 - 186.

Rosalin, Elin. 2008. Gagasan Merancang Pembelajaran Kontekstual. Bandung: Karsa Mandiri Persada

Sugiyono, 2009. Metode Penelitian Kuantitatif Kualitatif dan $R \& D$. Bandung: Alfabeta. 